\title{
Weekly Taxanes in the Treatment of Metastatic Breast Cancer
}

\author{
Hans-Joachim Lück Petra S. Vogel \\ Klinik für Gynäkologie und Gynäkologische Onkologie, Dr.-Horst-Schmidt-Kliniken, Wiesbaden, Germany
}

Key Words

Taxanes · Breast cancer, metastatic · Drug combination

\section{Summary}

Taxanes were developed in the 1990s for the treatment of metastatic breast cancer. Beginning with a 3-weekly schedule, in the last years the weekly schedule, especially for paclitaxel, became more and more common. The weekly schedules are characterized by a lower rate of side effects and better tolerability. The weekly taxane schedules are also a good platform for combinations with Carboplatin, Trastuzumab or Bevacizumab.

\section{Introduction}

Metastatic breast cancer, the chronic form of the disease, is incurable. Over the last 2 decades, the median 5-year survival rate has continuously increased. The use of anthracyclines, and especially the use of taxanes, since the 1990s has had an important influence of this increase. The first taxane, paclitaxel, commonly used at dosages of $175 \mathrm{mg} / \mathrm{m}^{2}$ every 3 weeks, showed promising activity in anthracyline-pretreated metastatic breast cancer. The main side effects are myelosupression, alopecia and neurological side effects. The necessity of cremophor in the paclitaxel formulation requires premedication with dexamethasone and $\mathrm{H} 1 / \mathrm{H} 2$ inhibitors. Combinations of the drug with anthracyclines and antimetabolites or vinca alkaloids achieve higher remission rates and longer progression-

\section{Schlüsselwörter}

Taxane $\cdot$ Mammakarzinom, metastasiertes · Kombinationstherapie

\section{Zusammenfassung}

Taxane wurden in den 1990er Jahren für die Therapie des metastasierten Mammakarzinoms entwickelt. Zunächst standen die 3-wöchentlichen Therapien im Vordergrund. In den letzten Jahren wurden aber immer häufiger wöchentliche Therapien eingesetzt, insbesondere bei Paclitaxel. Die wöchentlichen Therapien sind durch eine geringere Nebenwirkungsrate und eine bessere Verträglichkeit gekennzeichnet. Die wöchentliche Therapie mit Taxanen ist eine gute Basis für die Entwicklung von Kombinationstherapien mit Carboplatin, Trastuzumab oder Bevacizumab.

free survival (PFS), but do not change overall survival. The second taxane, docetaxel, developed some years later, showed higher tubulin affinity in vitro, but clinical results are very similar to paclitaxel. Docetaxel induces deep myelosupression, alopecia and also a form of neuropathy. Myelosuppression is associated with a high number of febrile neutropenia (FN) episodes. The use of colony stimulating factors decreases the rate of FN dramatically. Other side effects include nail changes and fluid retention syndrome. With docetaxel too, several combinations have been tested, showing similar results to paclitaxel but a higher number of severe side effects.

At the end of the 1990s, weekly schedules of both taxanes were developed. In summary, many phase II studies showed that weekly taxane schedules are associated with a lower rate of side effects, but show similar (docetaxel) or even higher

\begin{tabular}{|c|c|c|}
\hline KARGER & (C) 2006 S. Karger GmbH, Freiburg & $\begin{array}{l}\text { Prof. Dr. Hans-Joachim Lück } \\
\text { Dr.-Horst-Schmidt-Kliniken }\end{array}$ \\
\hline $\begin{array}{l}\text { Fax +497614520714 } \\
\text { E-mail Information@Karger.de } \\
\text { www.karger.com }\end{array}$ & $\begin{array}{l}\text { Accessible online at: } \\
\text { www.karger.com/brc }\end{array}$ & $\begin{array}{l}\text { Klinik für Gynäkologie und Gynäkologische Onkologie } \\
\text { Ludwig-Erhard-Straße 100, } 65199 \text { Wiesbaden, Germany } \\
\text { Tel. +49 } 611433411 \\
\text { E-mail hans-joachim.lueck@hsk-wiesbaden.de }\end{array}$ \\
\hline
\end{tabular}




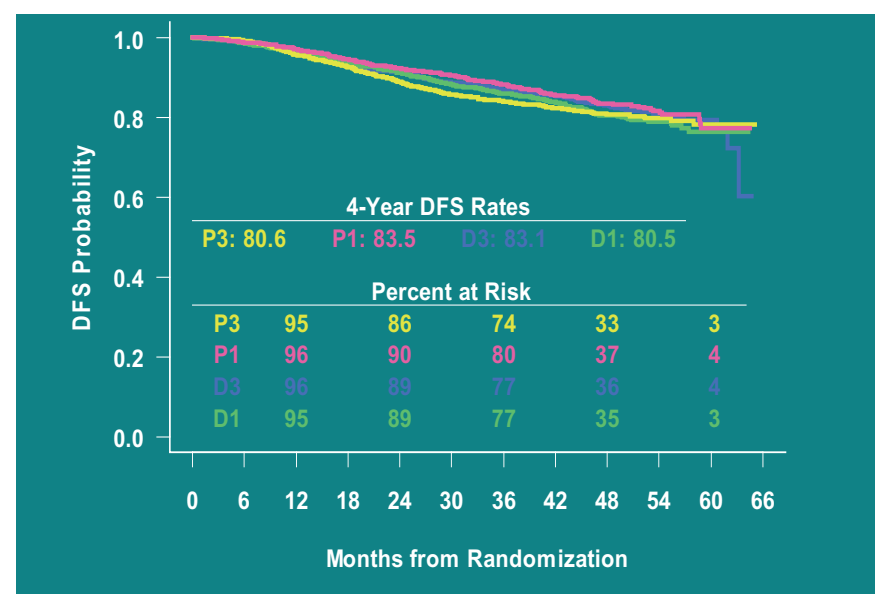

Fig. 1. $\mathrm{E}$ 1199: $\mathrm{AC} \rightarrow \mathrm{T}$ in node-positive or high-risk node-negative breast cancer patients - disease-free survival (DFS).

(paclitaxel) activity compared with 3-weekly schedules. Another important result was that premedication could be reduced without an increase in toxicity.

\section{Weekly Paclitaxel}

\section{Phase II Studies}

Several phase II studies have been carried out in metastatic breast cancer, most of them with mixed cohorts of chemotherapy pretreated and non-pretreated patients. Dosages between 80 and $100 \mathrm{mg} / \mathrm{m}^{2}$ where used in these studies. All studies showed a similar activity to the 3-weekly schedule, but at a decreased rate of side effects. Especially myelotoxicity was reduced in the weekly schedules. The response rates were between 22 and $53 \%$. An overview of these studies is shown in table 1 .

In our own trial [1], we used $90 \mathrm{mg} / \mathrm{m}^{2}$ every week. Treatment was stopped after 12 weeks. Patients with extensive liver metastasis started with $60 \mathrm{mg} / \mathrm{m}^{2}$. Two thirds of the patients had been pretreated with anthracyclines as first- or secondline therapy. $26(28 \%)$ patients responded (overall response rate (ORR): $31 \%$, complete remission (CR): 3 patients). The median time to progression was 7.1 months for responders. Patients who achieved stable disease had a progression-free interval of 4.1 months. Perez et al. [2] were able to show that weekly paclitaxel is an option for older metastatic patients. In this trial with 212 patients, $34 \%$ were older then 65 years. Efficacy and toxicity were no different to younger women.

\section{Phase III Studies}

Sikov et al. [2, 3] conducted a phase III study which compared 3 different weekly schedules. In arm A, the weekly dosage was $150 \mathrm{mg} / \mathrm{m}^{2}$ given 6 times every week with 2 weeks rest, followed by the same treatment again $(\operatorname{arm} \mathrm{A})$. In arm B, the same weekly dosage of paclitaxel was used, but patients received 2 treatments followed by 1 week rest. In the third arm,

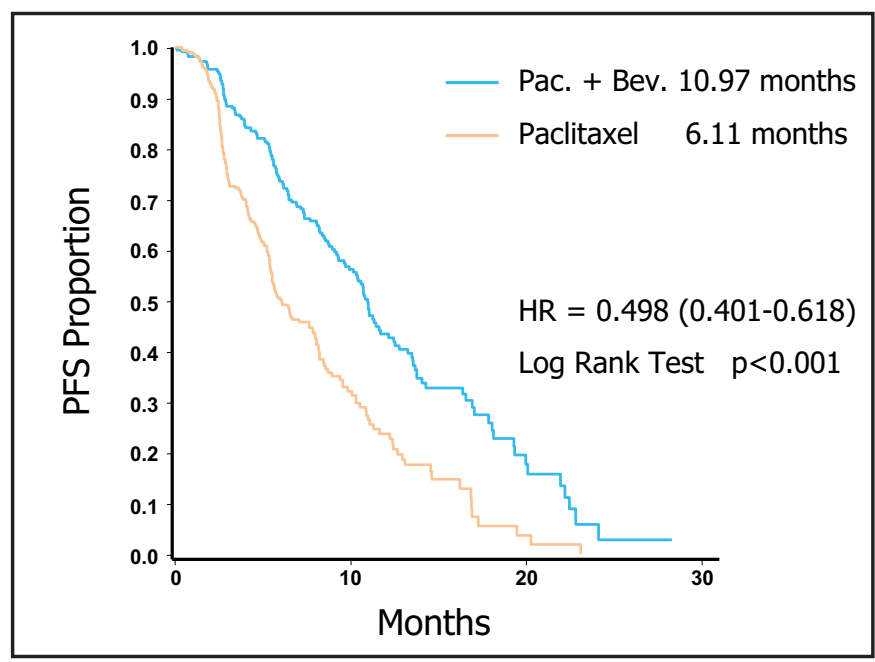

Fig. 2. Bevacizumab (Bev.) and paclitaxel (Pac.) weekly in metastatic breast cancer - progession-free survival (PFS) in E 2100

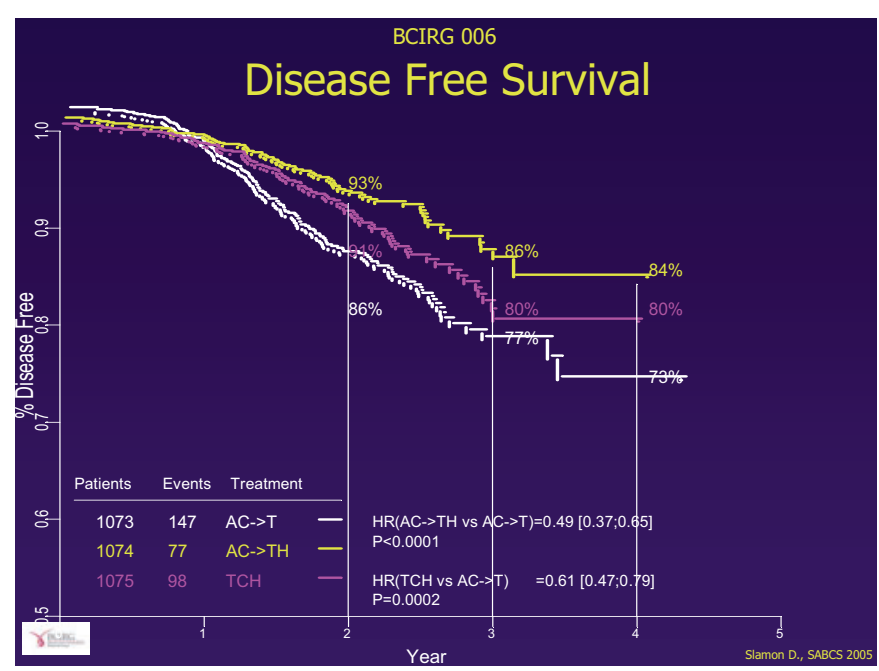

Fig. 3. BCIRG 006 - disease free survival (DFS).

paclitaxel was given at $80 \mathrm{mg} / \mathrm{m}^{2}$ every week for 15 weeks. In this study, the higher-dosage schedules produced no higher ORR but were associated with higher rates of toxicity compared to the 15-week schedule.

Sparano et al. [4] compared weekly taxane regimens with the 3 -weekly schedule, and paclitaxel with docetaxel in the adjuvant setting after 4 cycles of doxorubicin/cyclophosphamide (4×AC). No difference was found between any of the schedules or taxanes (fig. 1).

\section{Paclitaxel Combinations}

\section{Trastuzumab}

Different schedules of weekly treatment with paclitaxel in combination with trastuzumab were tested by several investi- 
Table 1. Weekly schedules of taxanes in metastatic breast cancer

\begin{tabular}{lllll}
\hline Study & $\begin{array}{l}\text { Dosage, } \\
\mathrm{mg} / \mathrm{m}^{2}\end{array}$ & $\begin{array}{l}\text { Prior therapy } \\
\text { (percentage of patients) }\end{array}$ & $\begin{array}{l}\text { ORR, } \\
\%\end{array}$ & $\begin{array}{l}\text { Patients, } \\
\mathrm{n}\end{array}$ \\
\hline Seidman et al. [12] & $100-120$ & $100 \% \geq 1$ & 40 & 16 \\
Marhenke et al. [13] & $40-90$ & $100 \% \geq 2(59 \% \mathrm{~A}, 38 \% \mathrm{~T})$ & 41 & 64 \\
Mickiewicz et al. [14] & $80-100$ & $100 \% \geq 1(\mathrm{~A})$ & 61 & 49 \\
Sikov et al. [3] & 175 & $31 \%$ adjuvant & 84 & 62 \\
Lück et al. [1] & 90 & $100 \% \geq 2$ met. regimens & 31 & 86 \\
Perez et al. [2] & 80 & $35 \%$ 1st-line & 22 & 212 \\
\hline
\end{tabular}

ORR = Overall response rate $; \mathrm{A}=$ doxorubicin, $\mathrm{T}=$ docetaxel.

Table 2. Combinations with trastuzumab

\begin{tabular}{lllll}
\hline Study & $\begin{array}{l}\text { Dosage, } \\
\mathrm{mg} / \mathrm{m}^{2}\end{array}$ & Prior therapy, $\mathrm{n}$ & $\begin{array}{l}\text { ORR, } \\
\%\end{array}$ & $\begin{array}{l}\text { Patients, } \\
\mathrm{n}\end{array}$ \\
\hline Fornier et al. [15] & $90(\times 2)$ & $3-4$ & 71 & 28 \\
Seidman et al. [16] & $90(\times 2)$ & $>2$ & 60 & 90 \\
Bangemann et al. [17] & $80-175(\times 2)$ & $79 \%$ of patients $(\mathrm{A}, \mathrm{T})$ & 50 & 90 \\
Scholz et al. [18] & $90(12$ weeks $\times 2)$ & $\begin{array}{l}>2 \text { chemotherapies } \\
\text { including high-dose }\end{array}$ & 50 & 24 \\
& & & \\
\hline
\end{tabular}

ORR = Overall response rate; $\mathrm{A}=$ doxorubicin, $\mathrm{T}$ = docetaxel.

Table 3. NCCTG 98-32-52: a randomized phase II trial comparing 3 -weekly carboplatin-paclitaxel-trastuzumab vs. weekly carboplatin-paclitaxel-trastuzumab - survival

\begin{tabular}{lll}
\hline & \multicolumn{2}{l}{ Regimen } \\
\cline { 2 - 3 } & 3-weekly $(\mathrm{n}=18)$ & weekly $(\mathrm{n}=18)$ \\
\hline 1-Year overall survival, \% & 89 & 100 \\
2-Year overall survival, \% & 50 & 81
\end{tabular}

gators (table 2). In one trial, paclitaxel was given 12 weeks in combination with trastuzumab, followed by trastuzumab alone until progression. In other trials, paclitaxel and trastuzumab were given together until progression. Overall, the response rates ranged from 50 to $87 \%$. Time to progression was approximately 9 months.

\section{Bevacizumab}

At the ASCO meeting 2005, Miller et al. [5] presented the first analysis of a randomized trial on first-line treatment of metastatic breast cancer, which compared weekly paclitaxel alone and in combination with bevacizumab. In this trial, the combination was more effective with respect to remission rates (14 vs. $29 \%$ ) and PFS (6 vs. 11 months) (fig. 2). Bevacizumab was given at $15 \mathrm{mg} / \mathrm{kg}$ every 3 weeks. The paclitaxel dose was $80 \mathrm{mg} / \mathrm{m}^{2}$ every week. The main side effect was hypertension which could be controlled easily by standard medication.

\section{Carboplatin-Paclitaxel}

Platinum-taxane combinations have been evaluated by several groups $[6,7]$. These combinations show similar efficacy to other combination therapies in metastatic breast cancer, including anthracycline-containing regimens. Their development was driven by preclinical data suggesting a synergistic effect of platinum salts and trastuzumab and demonstrating that these combinations are less cardiotoxic compared to anthracyclinecontaining combinations [8].

\section{Carboplatin-Paclitaxel-Trastuzumab}

Burris et al. [9] were able to show that the combination of carboplatin, paclitaxel and trastuzumab is very effective in the treatment of metastatic breast cancer. Rowland et al. [10] compared a 3-weekly schedule of carboplatin, paclitaxel and trastuzumab with a weekly schedule. In this study, the weekly schedule was superior in response rate and time to progression as well 1- and 2-year survival (table 3). The BCIRG 006 trial [11] compared a 3-weekly platinum-docetaxel-trastuzum$\mathrm{ab}$ combination with $4 \times \mathrm{AC}$ followed by docetaxel $(\times 4) /$ trastuzumab $(\times 52)$. The platinum-containing combination was as good as the anthracycline-containing regimen in diseasefree survival (DFS), and less cardiotoxic (fig. 3).

\section{Conclusion}

Weekly schedules of taxanes are characterized by good activity in metastatic breast cancer and a lower rate of side effects 
compared to the 3-weekly schedules. There is no difference in efficacy between the different taxanes, but paclitaxel was less toxic compared to docetaxel. Dose-dense therapies are only possible with paclitaxel. Weekly administration of paclitaxel is also the standard of care in adjuvant sequential anthracy- cline-containing chemotherapy regimens. The good tolerability and efficacy of weekly schedules make it seem logical to combine these therapies with new non-cytotoxic drugs, such as tyrosine kinase inhibitors or novel antibodies.

\section{References}

1 Lück H, Scholz U, Kühnle H: Weekly taxanes in treatment of metastatic breast cancer. Cancer Invest 2000;18(suppl):1-2.

2 Perez EA, Vogel CL, Irwin DH, et al.: Multicenter phase II trial of weekly paclitaxel in women with metastatic breast cancer. J Clin Oncol 2001;19: 4216-4223.

3 Sikov WM, Akerley W, Kahanic S, et al.: Multicenter, 3-arm randomized study of high-dose weekly paclitaxel (HDWP) versus standard-dose paclitaxel (SDWP) for metastatic breast cancer (MBC). Proc Am Soc Clin Oncol 2002;21:34a.

4 Sparano JA, Wang M, Martino S, et al.: Phase III study of doxorubicin-cyclophosphamide followed by paclitaxel or docetaxel given every 3 weeks or weekly in patients with axillary node-positive or high-risk node-negative breast cancer: results of North American Breast Cancer Intergroup Trial E1199. Breast Cancer Res Treat 2005;94(suppl 1): abstr 48.

5 Miller KD, Wang M, Gralow J, et al.: E2100: a randomized phase III trial of paclitaxel versus paclitaxel plus bevacizumab as first-line therapy for locally recurrent or metastatic breast cancer. Proc Am Soc Clin Oncol 2005.

6 Frasci G, D'Aiuto G, Comella P, et al.: Cisplatinepirubicin-paclitaxel weekly administration in advanced breast cancer: a phase I study of the Southern Italy Cooperative Study Group. Breast Cancer Res Treat 1999;56:239-152.

7 Loesch D, Robert N, Asmar L, et al.: Phase II multicenter trial of a weekly paclitaxel and carboplatin regimen in patients with advanced breast cancer. J Clin Oncol 2002;20:3857-3864.
8 Pegram MD, Konecny GE, O'Callaghan C, et al.: Rational combinations of trastuzumab with chemotherapeutic drugs used in the treatment of breast cancer. J Nat Cancer Inst 2004;96:739-749.

9 Burris H 3rd, Yardley D, Jones S, et al.: Phase II trial of trastuzumab followed by weekly paclitaxel/carboplatin as first-line treatment for patients with metastatic breast cancer. J Clin Oncol 2004;22: 1621-1629.

10 Rowland KM, Suman VJ, Ingle JN, et al.: Randomized phase II trial of weekly versus every 3-week administration of paclitaxel, carboplatin and trastuzumab in women with HER2 positive metastatic breast cancer. Proc Am Soc Clin Oncol 2003;22:8 (abstr 31).

11 Slamon D, Eiermann W, Robert N, et al.: Phase III randomized trial comparing doxorubicin and cyclophosphamide followed by docetaxel (AC_T) with doxorubicin and cyclophosphamide followed by docetaxel and trastuzumab (AC_TH), with docetaxel, carboplatin trastuzumab (TCH) in HERR2 positive early breast cancer patients: BCIRG 006 study. Breast Cancer Res Treat 2005;94(suppl 1): A1.

12 Seidman A, Murphy B, Hudis C, et al. Activity of taxol by weekly 1-hour infusion in patients (pts) with metastatic breast cancer (MBC): a phase II and pharmacologic study. Proc Am Soc Clin Oncol 1997; 16:148a(abstr 517).

13 Marhenke D, Lück HJ, Scholz U, et al.: Weekly paclitaxel for metastatic breast cancer (MBC). 8th International Congress Anti-Cancer Treatment 1998; abstr 16 .
14 Mickiewicz E, Alvarez AM, Brosio C, et al.: A promising second line treatment with weekly Taxol (T) in anthracycline recurrent, advanced breast cancer (ABC) patients (pts). Proc Am Soc Clin Oncol 1999;18:135a.

15 Fornier M, Seidman A, Esteva F, et al.: Weekly (W) Herceptin $(\mathrm{H})+1$ hour Taxol $(\mathrm{T})$ : phase II study in HER2 overexpressing $(\mathrm{H} 2+)$ and non-overexpressing (H2-) metastatic breast cancer (MBC). Proc Am Soc Clin Oncol 1999;18:126a.

16 Seidman A, Fornier M, Esteva F, et al.: Final report: weekly (W) Herceptin (H) and Taxol (T) for metastatic breast cancer (MBC): analysis of efficacy by HER 2 immunophenotype (immunhistochemistry $[\mathrm{IHC}]$ ) and gene amplification (fluorescent in-situ hybridisation [FISH]). Proc Am Soc Clin Oncol 2000;19:83a(abstr 319).

17 Bangemann N, Kuhle A, Willrodt RG, et al.: Treatment in HER2 overexpressing metastatic breast cancer (MBC) with trastuzumab (Herceptin) and chemotherapy. Breast Cancer Res Treat 2000;64: 123.

18 Scholz U, Lück HJ, Schippert C, Langer-Nitsche C, Kühnle H: Trastuzumab (Herceptin) combined with weekly paclitaxel in the treatment of metastatic breast cancer: a phase II study. Breast Cancer Res Treat 2000;64:527. 